\title{
Effectiveness of Stages in Village Fund Management (A Case Study on Implementation of Village Fund Management in Oenino-South Timor Tengah)
}

\author{
Ferdinan Imanuel Timo* Petrus Kase Pius Bumi Kelen \\ Master's Program in Administrative Science, Post Graduate Program, Universitas Nusa Cendana, Kupang, East \\ Nusa Tenggara, Indonesia
}

\begin{abstract}
Objective of the study is to describe and analyze (1) effectiveness of village fund management in Oenino, South Timor Tengah, and (2) inhibiting factors in village fund management in Oenino, South Timor Tengah. This qualitative study used a case-study approach. The focus of this study was 1 . to measure effectiveness of village fund management using 4 approaches, (Robins (1994: 58) namely: (1) goal-setting approach; (2) systems approach; (3) constituent approach, and (4) competitive advantage approach. 2. Supporting and inhibiting factors in implementation of village fund management in Oenino, South Timor Tengah. The setting of the study was all villages in Oenino, South Timor Tengah. Informants was selected based on purposive sampling technique, and the data collection techniques were interview, documentation, and observation. The data analysis technique was Miles and Huberman's Interactive Model. The method for validity testing was triangulation. The findings showed that effectiveness of village fund management in providing contribution to the society in Oenino, South Timor Tengah can be measured based on physical development and public empowerment. However, facilities the society can take advantage of the most were ones supporting agricultural programs, roads, clean water, health programs for instance Integrated Healthcare Center and Village Health Posts, and early childhood education program. Meanwhile, public empowerment which aimed to develop public-owned productive business is allocated for physical development for instance building houses, soccer field, public toilets, Integrated Healthcare Center cadre training and others that have yet to meet development of public-owned productive business. As the result, when explained further, the shift from public empowerment program to infrastructure development prevents society from working together.
\end{abstract}

DOI: $10.7176 / \mathrm{DCS} / 9-11-02$

Publication date: November $30^{\text {th }} 2019$

\section{BACKGROUND}

Central and regional government institutions are responsible for planning, implementation and supervision toward village fund management based on their levels. Village is given an ample opportunity to manage its own governance and carry out development program that aims to improve welfare of village society. As an addition, village government is expected to work independently in maintaining its governance and resources, including village budget and village asset management. This comes with an enormous responsibility. Therefore, village government should apply accountability principle, where in carrying their functions village government is responsible to community members.

Village government should work effectively. It means it has to meet an estimated target in a timely manner. Ya'kub (1984:39) stated that "work effectiveness is a situation that allows management to show how successful an organization is in meeting an estimated target." In other words, management should be able to help organization achieving its goals.

Village government is responsible for making Realized Village Fund Implementation Report and Realized Village Fund Implementation Accountability Report. Information these reports contain is obtained from one village fund management cycle, which starts from planning and budgeting; implementation and administration to reporting and accountability. In planning and budgeting stage, village government should involve village council (Badan Permusyawaratan Desa, BPD) to design programs and activities that acknowledge not only village community need and interest but also resources a village has. Besides that, village government should keep record, at least making financial report representing village government accountability. However, human resources village government has are still lacking. Village government has yet to establish a standard operating procedure or facilities and infrastructure for village fund management either. Furthermore, very few village community members are interested in how village funds are spent.

Since implementation of Village Fund from 2015 to 2017, an issue in village fund management in Oenino, South Timor Tengah is delay in Village Regulation issuance, which results in a delay in implementation of physical activities, administration affairs, Village Fund reporting and accountability reporting.

The following is information on Village Fund Management in Oenino between 2016 and 2017. 
Table 1.1.Steps in Village Fund Management in Oenino, South Timor Tengah during 2016 and 2017 Fiscal Year

\begin{tabular}{|c|c|c|c|c|c|c|c|}
\hline \multirow{3}{*}{ No } & \multirow{3}{*}{ Village } & \multicolumn{6}{|c|}{ Village Fund Management } \\
\hline & & \multicolumn{2}{|c|}{$\begin{array}{c}\text { Establishment of Village Regulation } \\
\text { on Village Fund }\end{array}$} & \multicolumn{2}{|c|}{$\begin{array}{l}\text { Finalization of Physical } \\
\text { Activities }\end{array}$} & \multicolumn{2}{|c|}{$\begin{array}{l}\text { Accountability } \\
\text { Report }\end{array}$} \\
\hline & & 2016 & 2017 & 2016 & 2017 & 2016 & 2017 \\
\hline 1. & Oenino & $8 / 6 / 2016$ & $12 / 6 / 2017$ & Feb 2017 & $\begin{array}{l}\text { March } \\
2018\end{array}$ & $\begin{array}{l}\text { March } \\
2017\end{array}$ & $\begin{array}{l}\text { May } \\
2018\end{array}$ \\
\hline 2. & Neke & $21 / 7 / 2016$ & $13 / 7 / 2017$ & $\begin{array}{l}\text { March } \\
2017\end{array}$ & July 2018 & $\begin{array}{l}\text { March } \\
2017\end{array}$ & $\begin{array}{l}\text { July } \\
2018\end{array}$ \\
\hline 3. & Pene Utara & $7 / 7 / 2016$ & 9/7/2017 & Feb 2017 & June 2018 & $\begin{array}{l}\text { March } \\
2017\end{array}$ & $\begin{array}{l}\text { July } \\
2018\end{array}$ \\
\hline 4. & $\begin{array}{l}\text { Niki-niki } \\
\text { Un }\end{array}$ & $6 / 7 / 2016$ & $12 / 6 / 2017$ & Feb 2017 & June 2018 & $\begin{array}{l}\text { March } \\
2017\end{array}$ & $\begin{array}{l}\text { July } \\
2018\end{array}$ \\
\hline 5. & Hoi & $15 / 7 / 2016$ & $15 / 6 / 2017$ & Feb 2017 & $\begin{array}{l}\text { March } \\
2018\end{array}$ & $\begin{array}{l}\text { March } \\
2017\end{array}$ & $\begin{array}{l}\text { May } \\
2018\end{array}$ \\
\hline 6. & Abi & $18 / 7 / 2016$ & $10 / 7 / 2017$ & Feb 2017 & April 2018 & $\begin{array}{l}\text { March } \\
2017\end{array}$ & $\begin{array}{l}\text { May } \\
2018\end{array}$ \\
\hline 7. & Noenoni & $6 / 6 / 2016$ & $7 / 7 / 2017$ & Feb 2017 & May 2018 & $\begin{array}{l}\text { March } \\
2017\end{array}$ & $\begin{array}{l}\text { May } \\
2018\end{array}$ \\
\hline
\end{tabular}

Source : Regional Office of Oenino, South Timor Tengah, 2019.

Table 1.1. showed some issues village government encountered in 2016 and 2017 village fund management. One of which is delay in establishment of village fund. In general, it takes village government one month to establish village fund (January of the current year). However, it took Regional Office of Oenino six months to complete this process. 2016 and 2017 Oenino village was established in June and July. As the result, the village government was unable to meet its estimated targets, more particularly building infrastructure and facilities. It affects village fund disbursement in the following stage and as the result, village budget implementation is carried out at the end of 2016 and 2017.

Based on village fund management cycle, village regulation on Village Fund should be established by January of the current year and all physical programs should be completed by December 31 of that year. Village fund implementation accountability report should be finalized by January 10 the following year. Oenino village government has yet to follow this cycle. Therefore, the authors are interested in describing effectiveness of village fund management in Oenino, South Timor Tengah Selatan. This study focuses on factors that cause delay in Village Fund establishment in all villages in Oenino, South Timor Tengah.

Table 1.2. Village Fund Caps in Oenino, South Timor Tengah in 2015

\begin{tabular}{|c|l|c|c|r|r|}
\hline \multirow{2}{*}{ No } & \multirow{2}{*}{ Village Name } & \multicolumn{3}{|c|}{ Source of Funding } & \multirow{2}{*}{ Total Revenue } \\
\cline { 3 - 5 } & & ADD & DD & BHP & \multirow{2}{*}{ (248.978.088 } \\
\hline 1. & Neke & 292.920 .213 & 282.345 .540 & 4.541 .676 & 565.304 \\
\hline 2. & Pene Utara & 280.931 .724 & 279.528 .625 & 5.668 .884 & 581.187 .883 \\
\hline 3. & Noenoni & 325.311 .419 & 290.893 .929 & 5.087 .808 & 621.293 .156 \\
\hline 4. & Hoi & 228.106 .682 & 266.000 .531 & 4.123 .702 & 498.230 .915 \\
\hline 5. & Niki-Niki Un & 236.260 .915 & 268.088 .768 & 3.848 .958 & 508.198 .641 \\
\hline 6. & Oenino & 243.538 .191 & 269.952 .423 & 4.416 .019 & 517.906 .633 \\
\hline 7. & Abi & 1.856 .047 .232 & 1.928 .408 .602 & 33.087 .441 & 3.817 .543 .275 \\
\hline
\end{tabular}

Table 1.3. Village Fund Allocation in Oenino, South Timor Tengah in 2016

\begin{tabular}{|c|l|c|r|r|r|}
\hline No & Village Name & ADD & DD & \multicolumn{1}{|c|}{ BHP } & \multicolumn{1}{c|}{ Total Revenue } \\
\hline 1. & Neke & 265.655 .000 & 608.897 .000 & 4.430 .000 & 878.982 .000 \\
\hline 2. & Pene Utara & 315.561 .000 & 632.612 .000 & 5.872 .000 & 954.045 .000 \\
\hline 3. & Noenoni & 303.321 .000 & 626.795 .000 & 5.733 .000 & 935.849 .000 \\
\hline 4. & Hoi & 350.700 .000 & 649.309 .000 & 5.026 .000 & 1.005 .035 .000 \\
\hline 5. & Niki-Niki Un & 244.485 .000 & 598.836 .000 & 4.380 .000 & 847.701 .000 \\
\hline 6. & Oenino & 253.563 .000 & 603.150 .000 & 4.116 .000 & 860.829 .000 \\
\hline 7. & Abi & 262.380 .000 & 607.340 .000 & 4.663 .000 & 874.383 .000 \\
\hline & \multicolumn{1}{|c|}{ Total } & 1.995 .665 .000 & 4.326 .939 .000 & 34.220 .000 & 6.356 .824 .000 \\
\hline
\end{tabular}

Source : Regional Office of Oenino, South Timor Tengah, 2019.

Table 1.2 and 1.3 showed that village fund allocation from 2015 to 2016 is increasing, however village 
government of Oenino was unable to meet several targets. It is caused by a delay in village fund stipulation.

Table 1.4. Allocation of Unspent Fund (Silpa) from 2015 to 2017

\begin{tabular}{|r|l|r|r|r|r|r|r|}
\hline No & \multicolumn{1}{|c|}{ Village } & $\begin{array}{c}\text { Silpa from } \\
2015\end{array}$ & PAD & $\begin{array}{c}\text { Total Revenue } \\
\text { in 2016 }\end{array}$ & $\begin{array}{c}\text { Budget } \\
\text { Implementation }\end{array}$ & $\begin{array}{c}\text { Ratio (Silpa } \\
\text { in 2017) }\end{array}$ \\
\hline 1. & Neke & 109.532 .183 & 1 million & 989.514 .183 & 779.022 .019 & 78.7 & 210.492 .164 \\
\hline 2. & Pene utara & 79.928 .124 & & 1.033 .973 .124 & 844.022 .687 & 81.6 & 189.950 .437 \\
\hline 3. & Noenoni & 102.330 .181 & & 1.038 .179 .181 & 899.754 .800 & 86.7 & 138.424 .381 \\
\hline 4. & Hoi & 113.693 .156 & & 1.118 .728 .156 & 906.415 .450 & 81.0 & 212.312 .706 \\
\hline 5. & NikiNiki un & 123.801 .053 & & 971.502 .053 & 773.865 .181 & 79.7 & 197.636 .872 \\
\hline 6. & Oenino & 121.271 .385 & & 982.100 .385 & 813.089 .268 & 82.8 & 169.011 .117 \\
\hline 7. & Abi & 107.394 .572 & & 981.777 .572 & 755.175 .112 & 76.9 & 226.602 .460 \\
\hline & Total & 757.950 .654 & & 7.114 .774 .654 & 5.771 .344 .517 & 81.1 & 1.344 .430 .137 \\
\hline
\end{tabular}

Source : Regional Office of Oenino, South Timor Tengah, 2019.

Table 1.4 showed that unspent fund from 2015 to 2017 does not match its budget allocation. The amount of 2015 unspent fund for 2016-2017 fiscal year is similar to that of 2016 budget allocation.

Table 1.5. Village Fund Allocation in Oenino South Timor Tengah in 2017

\begin{tabular}{|c|c|c|c|c|c|}
\hline No & Village Name & ADD & DD & BHP & Total Revenue \\
\hline 1. & Neke & 266.089 .000 & 778.216 .000 & 3.500 .000 & 1.047 .805 .000 \\
\hline 2. & Pene Utara & 313.052 .000 & 807.443 .000 & 4.224 .000 & 1.124 .719 .000 \\
\hline 3. & Noenoni & 300.239 .000 & 799.469 .000 & 4.328 .000 & 1.104 .036 .000 \\
\hline 4. & Hoi & 347.669 .000 & 828.988 .000 & 4.021 .000 & 1.180 .678 .000 \\
\hline 5. & Niki-Niki Un & 243.784 .000 & 764.334 .000 & 3.188 .000 & 1.011 .306 .000 \\
\hline 6. & Oenino & 252.498 .000 & 769.757 .000 & 3.030 .000 & 1.025 .285 .000 \\
\hline \multirow[t]{2}{*}{7.} & Abi & 260.276 .000 & 774.598 .000 & 3.365 .000 & 1.038 .239 .000 \\
\hline & Total & 1.983 .607 .000 & 5.522 .805 .000 & 25.656 .000 & 7.532 .068 .000 \\
\hline
\end{tabular}

Source : Regional Office of Oenino, South Timor Tengah, 2019

2017 budget planning and programs keep showing a significant increase, and therefore, supervision is needed so that village community members can finish each program based on its target. Based on Oenino village government programs, several programs cannot be implemented due to time restriction.

Table 1.6. Village Program Implementation in Neke Village, Oenino

\begin{tabular}{|c|c|c|c|c|c|c|c|c|c|c|c|c|c|}
\hline \multirow{3}{*}{ No } & \multirow{3}{*}{$\begin{array}{c}\text { Criteria / } \\
\text { Implementation }\end{array}$} & \multicolumn{12}{|c|}{ Realized Budget } \\
\hline & & \multicolumn{3}{|c|}{2015} & \multicolumn{3}{|c|}{2016} & & \multicolumn{2}{|c|}{2017} & & \multicolumn{2}{|c|}{$2018 *$} \\
\hline & & $\begin{array}{c}\text { Target } \\
\text { (Rp) }\end{array}$ & $\begin{array}{c}\text { Realized } \\
\text { Budget } \\
\text { (Rp) } \\
\end{array}$ & $\%$ & Target (Rp) & $\begin{array}{c}\text { Realized } \\
\text { Budget } \\
\text { n (Rp) } \\
\end{array}$ & $\%$ & $\begin{array}{c}\text { Target } \\
\text { (Rp) }\end{array}$ & $\begin{array}{c}\text { Realized } \\
\text { Budget } \\
\text { (Rp) }\end{array}$ & $\%$ & $\begin{array}{c}\text { Target } \\
\text { (Rp) }\end{array}$ & $\begin{array}{c}\text { Realized } \\
\text { Budget } \\
\text { (Rp) }\end{array}$ & $\%$ \\
\hline 1. & $\begin{array}{l}\text { Village } \\
\text { Government }\end{array}$ & 212.679 .764 & 189.728 .000 & 89.2 & 266.827.857 & 242.659 .000 & 91 & 255.257 .857 & 251.850 .000 & 98.7 & & - & - \\
\hline 2. & Development & 234.545 .040 & 166.724 .621 & 71.1 & 528.756 .361 & 403.793.019 & 76 & 783.469 .247 & 757.463 .842 & 96.7 & 440.428 .769 & 242.002 .450 & 54.95 \\
\hline 3. & $\begin{array}{l}\text { Community } \\
\text { Development }\end{array}$ & 40.840 .000 & 28.150 .000 & 68.9 & 39.898 .907 & 29.350 .000 & 74 & 49.048.907 & 38.500 .000 & 78.5 & - & - & - \\
\hline 4. & $\begin{array}{l}\text { Community } \\
\text { Empowerment }\end{array}$ & 36.800 .500 & 30.730 .500 & 83.5 & 154.031 .058 & 103.220 .000 & 67 & 170.521 .153 & 165.697 .100 & 97 & 370437020 & 167.820 .200 & 45.3 \\
\hline & Total & 524.865.304 & 415.333.121 & 79.1 & 989.514.183 & 779.022 .019 & 78,7 & 1.258.297.164 & 1.213 .510 .942 & 96.4 & 810.865 .789 & 408.822 .650 & 50.4 \\
\hline
\end{tabular}

Source : Regional Office of Oenino, South Timor Tengah, 2019.

Note:*Target and Realized Budget in Stage I

Table 1.6 showed that Village Budget of Neke village in 2015 was 524,865,304 rupiahs and its Realized Village Budget was 415,333,121 rupiahs which means or at $79.1 \%$. Their ratio was $109,532,183$ rupiahs. This occurs every year in all villages in Oenino region. Other villages, regions and even cities/ municipalities hire supervisor to overcome the issue.

As an addition, the authors will also analyze how effective Village Fund management is. It refers to village government ability to allocate Village Fund to improve welfare of community members in Oenino. The authors are also interested in investigating the village community member's participation in establishment of the Oenino Village Fund, for instance initiation, planning, implementation, evaluation, utilization and reporting.

There are several factors affecting village fund management system. The authors also aim to identify supporting and inhibiting factors in village government management in Oenino, South Timor Tengah. These information is central for developing some strategies to optimize village fund management. 


\section{LITERATURE REVIEW}

\subsection{Effectiveness}

\subsubsection{Definisi Efektivitas}

Effectiveness is derived from the word effictive which means ability to carry out an activity successfully. Effectiveness according to an expert in management Drucker as cited in Handoko (2009: 7) is doing the things right. As an addition, Handoko (2007:7) argue that effectiveness is an ability to determine a target or an appropriate instrument to achieve an estimated goal. It can also mean ability of unit to ask its members to work together and achieve a set of targets, Gibson (1994).

Effectiveness refers to ability to use certain amount of resources, infrastructure and facilities to finish a task in timely manner Abdurahmat (2003: 92). It is accordance with Sondang P. Siagian (2001: 24) that effectiveness is to make use resource, facilities and infrastructure estimated previously to produce goods.

In the context of policy implementation, effectiveness means ability to generate output as a result of policy implementation (Islami, 1997:7). It refers to a process to achieve policy implementation targets.

\subsubsection{Approach in Effectiveness}

It is used to measure effectiveness of an activity. Starawaji (2009) stated that there are several approach to measure effectiveness, namely:

1. Target approach which measures the extent to which an institution can reach its targets;

2. Resource approach which measures effectiveness based on ability of an institution to obtain various required resources;

3. Process approach which uses efficiency and condition of an internal institution to measure effectiveness.

\subsubsection{Measuring Effectiveness}

Some of the following theories can be used to measure effectiveness, for example: (1) goal-setting approach; (2) systems approach; (3) constituent approach, and (4) competitive advantage approach, Robins (1994: 58). Goal-setting approach is the most frequent criterion used to measure effectiveness. Steers (1977: 44) argue that effectiveness should be measured based on both univariance (overall achievement, productivity, satisfaction, profit and turnover of employee) and multivariance (measuring effectiveness based on facilities and goals of organization). According to Steers, as cited in Price, effectiveness can also be measured based on combination of the following indicators, namely: (1) adaptability, (2) productivity, (3) job satisfaction, (4) profitability, and (5) resource-seeking.

\subsubsection{Factors Affecting Effectiveness}

Conceptual framework is used to identify four variables associated to effectiveness: (1) characteristics of an organization; (2) characteristics of environment; (3) characteristics of employees; and (4) policy and management, Steers (1977:209). Based on experts' opinions of effectiveness, it can be concluded that effectiveness is a condition in which goals of an activity or program can be achieved well in a timely manner. Related to the focus of this study, effectiveness refers to implementation of village fund management plan and program based on village management procedures and stages.

\subsection{Conceptual Framework}

Decentralization results in recognition toward village. Act of 2014 number 6 on village stated that: central government protects and empowers village into a developed, resourceful, independent and democratic as a strong foundation of welfare of community.

Village fund provides ample opportunity for village to develop a realistic development plan that matches both its potentials and its needs. Its amount its pretty significant. 
Figure 2.3 Conceptual Framework

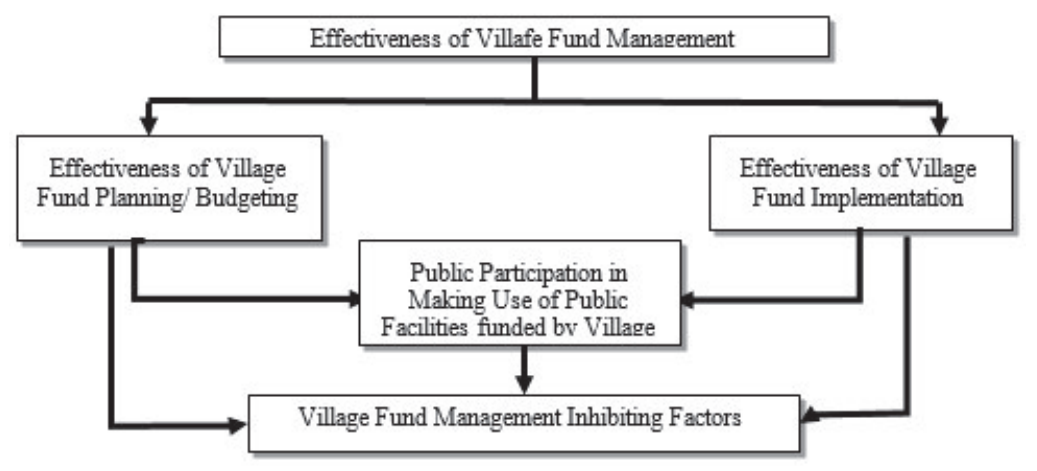

\subsection{Village and Village Fund Management}

\subsubsection{Village}

Village is an ancient form of community where thousands of individual live together and thus, are familiar with one another; most of these people are farmers, fishermen or run businesses that depend heavily on the nature; one will find close-knit family bond, obedience and social rules there, P. J. Bournen in Nurcholis (2001:4). Bintarto (1983) stated that village is geographical, social, economic, political and cultural manifestation that exists in an area and this area has a mutual relationship with another/other areas. In conclusion, village refers to an area where a number of household lives and develops an independent government system (Head of Village is in charge of this system) or a group of houses outside a city.

\subsubsection{Village Fund Management}

1. Village Fund Management Concept

Management is a process, method or act of managing. Management is soft skills or skills to achieve a certain goal with the help of others, Sondang P. Siagian (1997: 34). Village Fund is a manifestation of implementation Act of 2014 number 6 on villages. Source of funding of Village Funds is State Fund. Its objective is to develop public facilities and eventually standard of living in rural areas.

Figure 2.1 Village Fund Management Cycle

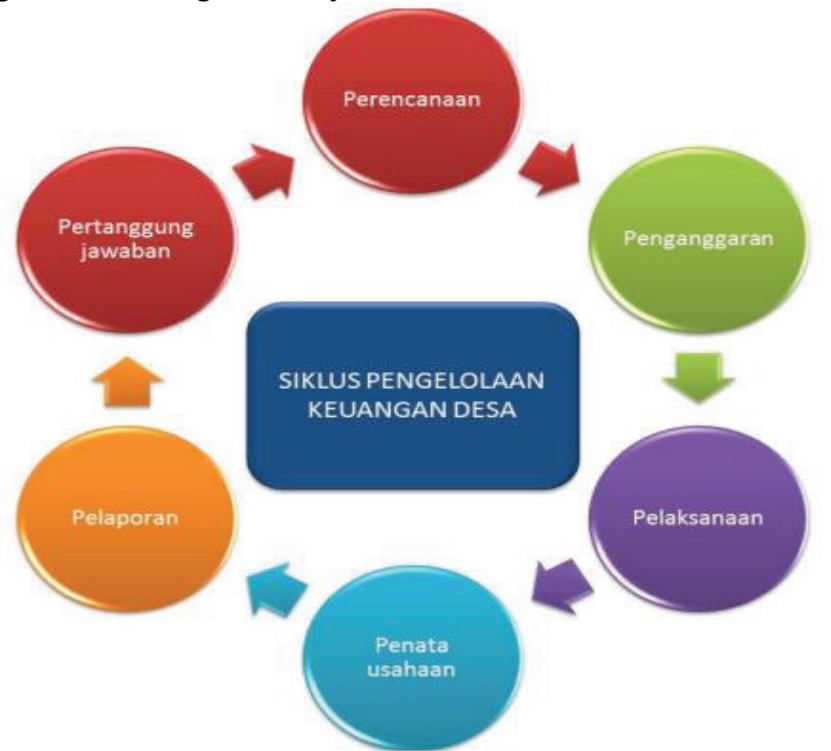

Village fund is transferred from State Fund through Regional Fund and spent to fund administration system in rural areas, development program, public development and public empowerment.

\section{METHODOLOGY}

This study was a qualitative study and its design was a case study. The focus of this study was 1. to measure effectiveness of village fund management using 4 approaches, (Robins (1994: 58) namely: (1) goal-setting approach; (2) systems approach; (3) constituent approach, and (4) competitive advantage approach. 2. Supporting and inhibiting factors in implementation of village fund management in Oenino, South Timor Tengah. The setting 
of the study was all villages in Oenino, South Timor Tengah. Informants was selected based on purposive sampling technique, and the data collection techniques were interview, documentation, and observation. The data analysis technique was Miles and Huberman's Interactive Model. The method for validity testing was triangulation.

\section{RESULTS AND DISCUSSIONS}

\subsection{Analysis on Effectiveness of Village Fund Management in Oenino, South Timor Tengah}

Based on the authors' observations, head of villages in Oenino referred to central government guideline in implementation of village fund management. The guideline consists of some stages both village government and community members should go through. It emphasizes on public participation as business owners in those villages. The goal-setting approach, systems approach; constituent approach; and competitive advantage approach lost its meaning without village funds. According to the author, village fund is a manifestation of central government program of which goal is to develop rural areas.

\subsubsection{Analysis on Effectiveness of Village Fund Planning/Budgeting}

Village government plans its development plan based on middle-term village development plan (RPJM Desa) and annual village development plan (RKP Desa) RPJM Desa is valid for 6 (six) years while RKP Desa is valid for 1 (one) year. RKP Desa is elaboration of RPJM Desa. It is developed based on a discussion which is conducted at least every June each year.

If it runs well, village fund management will benefit rural community members (see Figure 4.4). It requires a competent human resource and a suitable financial procedures. Therefore, government of South Timor Tengah should develop a robust financial system that consists of organization responsible for village fund management, job description of this organization, flowchart and a set of criteria.

\subsubsection{Analysis on Effectiveness of Village Fund Budgeting}

Some village community members in Oenino have yet been able to take advantage of Oenino village fund. As the result, there is a delay in establishment of village fund. The village community members were not as responsive toward the stages of village fund estimation. There is room we should pay attention to through the stages of village fund establishment and we can continue on amendment of village fund on the current year.

\subsubsection{Analysis on Effectiveness of Village Fund Implementation in Village Funds based on Pubic} Empowerment Program

Indirect advantages of village funds are infrastructure building, for instance village road, bridges, early childhood education institution, and integrated healthcare center. The infrastructure has double impact even though some community members have yet to make use of them. Take village road as an example. There are a lot of benefits village community members can get when village government build a new road or repair potholes and cracks on an existing road. Villages in Oenino are getting more accessible as means of public transportation is improving in terms of number and quality. In other words, infrastructure can improve welfare of village community members.

\subsection{Factors Inhibiting Effectiveness of Village Fund Management Planning and Budgeting through Village Fund in Oenino South Timor Tengah \\ 4.2.1. Internal Factors}

Factor that hinders implementation of village fund for infrastructure building and public facilities are human resource, information, and public participation.

\subsubsection{External Factors}

Factors that hinder implementation of village fund for public empowerment program (noninfrastructure building program) are human resource, information, and public participation.

\section{CONCLUSION}

Effectiveness of village fund management toward welfare of village community members in Oenino South Timor Tengah can be measured based on infrastructure building and public empowerment program. Benefit of village fund the community members experience the most is in the form of infrastructure building, more particularly one related to agriculture, road, clean water and health facilities in the form of Integrated Healthcare Center and Village Health Post, and early childhood education institution. Meanwhile, public empowerment which aimed to develop public-owned productive business is allocated for physical development for instance building houses, soccer field, public toilets, Integrated Healthcare Center cadre training and others that have yet to meet development of publicowned productive business. As the result, when explained further, the shift from public empowerment program to infrastructure development prevents society from working together.

Main factor inhibiting implementation of village fund management in Oenino South Timor Tengah is lack of information on village fund allocation and village fund establishment. Another inhibiting factor is human resource. Very few village government staffs, and village community members participate in creating business 
that allows village community members to earn more money. Village community members in Oenino are consumptive and therefore, depend heavily on the government.

\section{SUGGESTION}

1. Government of South Timor Tengah through Department of Public Empowerment should make a set of priority prior to allocating village funds to several posts;

2. Supervision team should conduct evaluation on whether or not village government invite village community members to participate in public empowerment program. As an addition, supervision team should make sure village government carry out all targeted activities and conduct activities with different theme in a year;

3. Village government should allocate village fund for public empowerment program of which objective is to create business entity that eradicate poverty and decrease public dependence towards government, instead of spending the fund for building infrastructure and public facilities;

4. Village community members should participate actively in public empowerment program. Active participation allows students to work together and monitor whether or not village fund is allocated effectively.

\section{REFERENCES}

Abrudahmat. 2003. Pengertian Efektivitas. Universitas Negeri Yogyakarta : Lumbung Pustaka.

Adisasmita, Rahardjo. 2011. Manajemen Pemerintahan Daerah. Yogyakarta : Graha Ilmu

Adrian. Payne. 2001. The Essence of Service Marketing. Yogyakarta :Andi dan Pearson Education (Asia) Pte.LTd.

Badan Pengawasan Keuangan dan Pembangunan RI, 2015. Petunjuk Pelaksanaan Bimbingan dan Konsultasi Pengelolaan Keuangan Desa. Jakarta.

2018. Petunjuk Pelaksanaan Bimbingan dan Konsultasi Pengelolaan Keuangan Desa. Jakarta.

Bintarto R, 1983. Interaksi Desa-Kota dan Permasalahannya. Jakarta : Ghalia Indonesia..

D. Conyers and Hill. 1984. Konsep Perencanaan Pembangunan.

Gibson, James L., John M. Ivancevich dan James H. Donnelly Jr., 1994.Organizations Behavior: Behavior, Structure, Process. Terjemahan: Nunuk Adriani. Jakarta: Binarupa Aksara.

Handoko, T. Hani. 2009, Manajemen. Yogyakarta : Penerbit BPEE.

Haryanto, 2008. Perencanaan Pengajaran. Jakarta : Rineka Cipta.

Hasibuan, Malayu S.P., 2002. Manajemen Sumber Daya Manusia. Jakarta : Bumi Aksara.

Hanif, Nurcholis. 2001. Pertumbuhan dan Penyelenggaraan Pemerintah. Jakarta : Erlangga

Islamy, M. Irfan.1997. Prinsip-prinsip Perumusan Kebijaksanaan Negara. Jakarta : Sinar Grafika

Kantor Kecamatan Oenino, 2019. Laporan Pengelolaan Keuangan Desa di Wilayah Kecamatan Oenino Kabupaten Timor Tengah Selatan.

Mardiasmo, 2002. Akuntansi Sektor Publik. Yogyakarta : Andi Offset. ,2004. Akuntansi Sektor Publik. Yogyakarta : Andi Offset

Miles, Mathew. B. dan A. Michael Huberman. Analisis data Kualitatif. Terjemahan Thjejep Rohendi Rohidi. Jakarta : Universitas Indonesia.

Robbins, Stephen P., 1994. Teori Organisasi : Struktur, Desain dan Aplikas. Alih Bahasa Jusuf Udaya, Jakarta, Arcan.

2010. Manajemen. Jakarta, PT. Index Kelompok Gramedia

Siagian, Sondang P., 1978. Manajemen. Yogyakarta : Liberty

,1985. Administrasi Pembangunan. Jakarta : Bumi Aksara.

1991. Organisasi Kepemimpinan dan Perilaku Administrasi. Jakarta : PT. Gunung Agung.

Siswanto, Bejo., 2005. Manajemen Tenaga Kerja Indonesia Pendekatan Administratif dan Operasional, Jakarta : Bumi Aksara.

Steers, Richard M., 1977. Efektivitas Organisasi. Seri Manajemen No. 47. Jakarta : Erlangga 1998. Efektivitas Organisasi. Seri Manajemen. Jakarta : Erlangga

Sugiyono. 2004. Metode Penelitian Kuantitatif, Kualitatif dan R\&D. Bandung : Alfabeta 2007. Metode Penelitian Pendidikan Pendekatan Kuantitatif, Kualitatif, dan R\&D. Bandung : Alfabeta. .2009. Metode Penelitian Kuantitatif, Kualitatif, dan R\&D. Bandung : Alfabeta 2010. Metode Penelitian Kualitatif, dan R\&D. Bandung: Alfabeta.

2014. Metode Penelitian Kualitatif, Kuantitatif dan Kombinasi (Mixed Methods). Bandung: Alfabeta. Susanto, Azhar. 2005. Sistem Informasi Manajemen. Jakarta : Ghalia Indonesia.

Undana, Lembaga Penelitian dan Pengabdian Masyarakat. 2018. Penelitian Penyusunan Data Dan Informasi Pemanfaatan Dana Desa Di Provinsi Nusa Tenggara Timur. Kupang.

Ya’kub, Hamzah. 1984. Menuju Keberhasilan Manajemen danKepemimpinan. Jakarta: CV. Mas Agung. 


\section{LEGISLATION:}

Undang-Undang Nomor 6 Tahun 2014 tentang Desa

Undang-Undang Nomor 23 Tahun 2014 tentang Pemerintah Desa

Peraturan Pemerintah Nomor 43 Tahun 2014 tentang Peraturan Pelaksanaan UU Nomor 6 Tahun 2014 tentang Desa.

Peraturan Pemerintah Nomor 60 Tahun 2014 tentang Dana Desa Yang Bersumber dari Anggaran Pendapatan dan Belanja Negara.

Peraturan Presiden Nomor 12 Tahun 2015 tentang Kementerian Desa, Pembangunan Daerah Tertinggal dan Transmigrasi.

Peraturan Menteri Dalam Negeri Nomor 111 Tahun 2014 tentang Pedoman Teknis Peraturan di Desa.

Peraturan Menteri Dalam Negeri Nomor 113 Tahun 2014 tentang Pengelolaan Keuangan Desa.

Peraturan Menteri Dalam Negeri Nomor 114 Tahun 2014 tentang Pedoman Pembangunan Desa.

Peraturan Menteri Keuangan Nomor 241/PMK.07/2014 tentang Pelaksanaan dan Pertanggungjawaban Transfer ke Daerah dan Dana Desa.

Peraturan Menteri Keuangan Nomor 250/PMK.07/2014 tentang Pengalokasian Transfer ke Daerah dan Dana Desa.

Peraturan Menteri Keuangan Nomor 263/PMK.05/2014 tentang Sistem Akuntansi dan Pelaporan Keuangan Transfer ke Daerah dan Dana Desa.

Peraturan Menteri Desa PDTT Nomor 19 Tahun 2017 tentang Penetapan Prioritas Dana Desa 2018.

Peraturan Menteri Desa, Pembangunan Daerah Tertinggal, dan Transmigrasi Nomor 3 Tahun 2015 tentang Pendampingan Desa.

Perbup No. 1 Tahun 2018 tentang Tata Cara Pembagian dan Penetapan Rincian Dana Desa Setiap Desa Di Kabupaten Timor Tengah Selatan Tahun Anggaran 2018. 